\title{
Contribution of liquid, NAT and ice particles to chlorine activation and ozone depletion in Antarctic winter and spring
}

\author{
O. Kirner ${ }^{1}$, R. Müller ${ }^{2}$, R. Ruhnke ${ }^{3}$, and H. Fischer ${ }^{3}$ \\ ${ }^{1}$ Karlsruhe Institute of Technology, Steinbuch Centre for Computing (SCC), Karlsruhe, Germany \\ ${ }^{2}$ Research Centre Jülich GmbH, Institute of Energy and Climate Research - Stratosphere (IEK-7), Jülich, Germany \\ ${ }^{3}$ Karlsruhe Institute of Technology, Institute for Meteorology and Climate Research (IMK), Karlsruhe, Germany \\ Correspondence to: O. Kirner (ole.kirner@kit.de)
}

Received: 24 April 2014 - Published in Atmos. Chem. Phys. Discuss.: 5 June 2014

Revised: 14 January 2015 - Accepted: 21 January 2015 - Published: 24 February 2015

\begin{abstract}
Heterogeneous reactions in the Antarctic stratosphere are the cause of chlorine activation and ozone depletion, but the relative roles of different types of polar stratospheric clouds (PSCs) in chlorine activation is an open question. We use multi-year simulations of the chemistryclimate model ECHAM5/MESSy for Atmospheric Chemistry (EMAC) to investigate the impact that the various types of PSCs have on Antarctic chlorine activation and ozone loss.

One standard and three sensitivity EMAC simulations have been performed. In all simulations a Newtonian relaxation technique using the ERA-Interim reanalysis was applied to simulate realistic synoptic conditions. In the three sensitivity simulations, we only changed the heterogeneous chemistry on PSC particles by switching the chemistry on liquid, nitric acid trihydrate (NAT) and ice particles on and off. The results of these simulations show that the significance of heterogeneous reactions on NAT and ice particles for chlorine activation and ozone depletion in Antarctic winter and spring is small in comparison to the significance of heterogeneous reactions on liquid particles. Liquid particles alone are sufficient to activate almost all of the available chlorine, with the exception of the upper PSC regions between 10 and $30 \mathrm{hPa}$, where temporarily ice particles show a relevant contribution. Shortly after the first PSC occurrence, NAT particles contribute a small fraction to chlorine activation.

Heterogeneous chemistry on liquid particles is responsible for more than $90 \%$ of the ozone depletion in Antarctic spring in the model simulations. In high southern latitudes, heterogeneous chemistry on ice particles causes only up to $5 \mathrm{DU}$ of additional ozone depletion in the column and heterogeneous chemistry on NAT particles less than $0.5 \mathrm{DU}$.
\end{abstract}

The simulated $\mathrm{HNO}_{3}, \mathrm{ClO}$ and $\mathrm{O}_{3}$ results agree closely with observations from the Microwave Limb Sounder (MLS) onboard NASA's Aura satellite.

\section{Introduction}

Polar stratospheric clouds (PSCs) consist of supercooled ternary solution (STS, type 1b PSC), nitric acid trihydrate (NAT, type 1a PSC) and ice particles (type 2 PSC). An accurate representation of PSCs and sulphuric acid background/water (binary) aerosol is essential for the correct simulation of chlorine activation and polar ozone depletion in chemistry-climate models (CCMs). The liquid (cold binary aerosols and STS particles) and solid particles (NAT and ice particles) allow heterogeneous reactions to proceed, which cause the activation of chlorine reservoirs (Solomon et al., 1986) and the production of chlorine radicals leading to ozone destruction. In addition, NAT particles cause denitrification of the stratosphere, resulting in a delay in the deactivation of active chlorine in polar spring (e.g. Toon et al., 1986; Lowe and MacKenzie, 2008).

Here we revisit the question of the importance of different types of PSC and stratospheric aerosol for heterogeneous chlorine activation and ozone depletion in Antarctic winter and spring using the submodel PSC (Kirner et al., 2011) of the chemistry-climate model ECHAM5/MESSy for Atmospheric Chemistry (EMAC, Jöckel et al., 2006).

Over the last years a discussion developed about the different contribution of cold binary aerosols, as well as STS, NAT and ice particles to chlorine activation. Drdla and Müller 
(2012) have raised the question of the necessity of NAT and ice particles for reaching the full polar stratospheric chlorine activation. They further argue that even the heterogeneous reactivity on cold binary aerosol is sufficient to explain the major fraction of polar stratospheric chlorine activation. In contrast, Solomon et al. (2014) have argued that in sunlit air in the polar stratosphere, deactivation, i.e. the reformation of $\mathrm{HCl}$ and $\mathrm{ClONO}_{2}$, increases the rate at which heterogeneous reactions must proceed to keep pace with deactivation.

Wegner et al. (2012) examined the importance of the cold binary aerosols for chlorine activation in the Arctic winters 2004/2005 and 2009/2010 with the help of in situ observations. They concluded that the surface area provided by PSCs did not significantly impact chlorine activation rates in these both winters. Wohltmann et al. (2013) showed, based on simulations of the Arctic winter 2009/2010 with the Lagrangian model ATLAS, that liquid aerosols alone allow to explain the observed mixing ratios of active chlorine and ozone from Microwave Limb Sounder (MLS), Atmospheric Chemistry Experiment - Fourier Transform Spectrometer (ACE-FTS) and in situ measurements.

However, in these Arctic studies the contribution of ice particles to chlorine activation was not investigated and there is still the question if liquid particles are also sufficient to activate the complete inorganic chlorine during Antarctic winters. Therefore, we performed a standard EMAC simulation from 2000 to 2012 and three additional sensitivity simulations from 2005 to 2012 with different assumptions for heterogeneous chemistry on stratospheric aerosol and PSC particles. By comparing the results of the EMAC standard and sensitivity simulations it is possible to determine the contribution of liquid particles (in EMAC the cold binary aerosols and STS particles are not distinguished, see Kirner et al., 2011), NAT particles and ice particles to chlorine activation in polar winter and to determine the corresponding ozone depletion in polar spring.

For comparison of our model results with observations we choose the Earth Observing System (EOS) MLS (Waters et al., 2006) onboard NASA's Aura satellite.

\section{The EMAC model}

The ECHAM/MESSy Atmospheric Chemistry (EMAC) model is a numerical chemistry and climate simulation system that includes submodels describing tropospheric and middle atmosphere processes and their interaction with oceans, land and human influences (Jöckel et al., 2006). It uses the Modular Earth Submodel System (MESSy) to link multi-institutional computer codes (Jöckel et al., 2005). The core atmospheric model is the 5th generation European Centre Hamburg general circulation model (ECHAM5, Roeckner et al., 2006). For the present study we applied EMAC (ECHAM5 version 5.3.01, MESSy version 1.10) in the T42L39MA-resolution, i.e. with a spherical truncation of T42 (corresponding to a quadratic Gaussian grid of approximately $2.8^{\circ}$ by $2.8^{\circ}$ in latitude and longitude) with 39 vertical hybrid pressure levels up to $0.01 \mathrm{hPa}$ (approximately $80 \mathrm{~km}$ ) and with a time step of $10 \mathrm{~min}$. The approximate vertical resolution in the stratosphere is between 1.5 and $2.5 \mathrm{~km}$ decreasing with altitude.

Besides the submodel MECCA1 (Sander et al., 2005) for the calculation of gas-phase chemistry and the submodel PSC for the simulation of polar stratospheric clouds (Kirner et al., 2011) among others the following submodels have been used in our study: OFFLEM for offline emissions of trace gases and aerosols, TNUDGE for tracer nudging (both Kerkweg et al., 2006), JVAL for the calculation of photolysis rates (Landgraf and Crutzen, 1998), CONVECT for the parameterisation of convection (Tost et al., 2006), $\mathrm{H}_{2} \mathrm{O}$ for stratospheric water vapour, RAD4ALL for the radiation calculation, and HETCHEM for calculating reaction rate coefficients of heterogeneous reactions on aerosols (see Jöckel et al., 2006, and references therein).

Reaction rate coefficients for gas phase reactions and absorption cross sections for photolysis are taken from Atkinson et al. (2007) and Sander et al. (2011).

A Newtonian relaxation technique for the prognostic variables temperature, vorticity, divergence and the surface pressure is implemented in EMAC to reproduce realistic synoptic conditions. We applied this nudging technique in our simulations above the boundary layer and below $1 \mathrm{hPa}$ with nudging strengths as recommended in van Aalst (2005) using the ERA-Interim reanalysis (Dee et al., 2011) from the European Centre for Medium-range Weather Forecasts (ECMWF).

\section{The submodel PSC}

The submodel PSC is based on the "Mainz Photochemical Box Model" (Crutzen et al., 1992; Müller et al., 1994; Grooß, 1996; Meilinger, 2000) and was improved and extended by Buchholz (2005) and Kirner (2008). The submodel PSC simulates the number densities, mean radii and surface areas of liquid sulphuric acid aerosols, STS, NAT and ice particles. Different sedimentation schemes for these particles are included (the trapezoid scheme is used in our simulations (Buchholz, 2005)). Together with the submodels HETCHEM and MECCA1 the reaction rate coefficients and reaction rates of all heterogeneous reactions are calculated, which are important for the ozone depletion in polar spring.

Heterogeneous reaction rates and their temperature dependencies on NAT were calculated according to the parameterisation of Carslaw and Peter (1997) based on the measurements of Hanson and Ravishankara (1993). Carslaw and Peter (1997) also developed a parameterisation for heterogeneous reactions on NAT based on the measurements of Abbatt and Molina (1992). Using the latter parameterisation results in substantially lower (by a factor of more than 50) heterogeneous reactivity on NAT and in a significantly reduced 
Table 1. The eight size bins in submodel PSC used for the kinetic growth NAT parameterisation.

\begin{tabular}{lrrrrrrrr}
\hline Size bin & 1 & 2 & 3 & 4 & 5 & 6 & 7 & 8 \\
\hline Minimum NAT radius $(\mu \mathrm{m})$ & 0.0 & 0.2 & 1.0 & 2.0 & 6.0 & 9.0 & 12.0 & 16.0 \\
Maximum NAT radius $(\mu \mathrm{m})$ & 0.2 & 1.0 & 2.0 & 6.0 & 9.0 & 12.0 & 16.0 & 20.0 \\
Mean NAT radius $\left(r_{\mathrm{NAT}_{\text {bin }}}\right.$ in $\left.\mu \mathrm{m}\right)$ & 0.1 & 0.6 & 1.5 & 4.0 & 7.5 & 10.5 & 14.0 & 18.0 \\
Maximum of NAT number density & 3.28 & 3.28 & 3.28 & 3.28 & 3.28 & 3.28 & 1.64 & 1.64 \\
$\left(N_{\mathrm{NAT}_{\text {bin }}}\right.$ in $10^{-5}$ particles cm & \\
\hline
\end{tabular}

chemical ozone loss (Carslaw et al., 1997); therefore this latter parameterisation was not considered here.

The heterogeneous reaction rate coefficients on liquid particles are taken from Hanson and Ravishankara (1994) and Hanson et al. (1994). An alternative parameterisation for reactions on liquid particles was reported by Shi et al. (2001), which results however in a heterogeneous reactivity very close to the one employed here (e.g. Wegner et al., 2012).

The heterogeneous reactivity of ice particles is much larger than that of other types of PSCs because of the much larger surface area of ice PSCs; the uptake coefficients and reaction probabilities for ice particles are taken from Sander et al. (2011).

The formation of STS $\left(\mathrm{HNO}_{3}-\mathrm{H}_{2} \mathrm{SO}_{4}-\mathrm{H}_{2} \mathrm{O}\right)$ in the model is based on Carslaw et al. (1995) and occurs through uptake of nitric acid $\left(\mathrm{HNO}_{3}\right)$ by liquid sulphuric acid (binary) aerosols $\left(\mathrm{H}_{2} \mathrm{SO}_{4}-\mathrm{H}_{2} \mathrm{O}\right)$ (described in detail in Kirner et al., 2011).

The formation of ice particles in the model is based on the thermodynamic approach of Marti and Mauersberger (1993) with

$\mathrm{H}_{2} \mathrm{O}($ ice $)=\frac{\left(e_{\mathrm{H}_{2} \mathrm{O}(\text { total })}-E_{\mathrm{H}_{2} \mathrm{O}}^{\mathrm{ice}}\right)}{p}$.

The ratio of ice phase to dry air $\left(\mathrm{H}_{2} \mathrm{O}\right.$ (ice) in $\left.\mathrm{mol} \mathrm{mol}^{-1}\right)$ depends on the difference of the total partial pressure of $\mathrm{H}_{2} \mathrm{O}$ $\left(e_{\mathrm{H}_{2}} \mathrm{O}\right.$ (total) in $\mathrm{Pa}$ ) and the saturation vapour pressure of $\mathrm{H}_{2} \mathrm{O}$ over ice particles $\left(E_{\mathrm{H}_{2} \mathrm{O}}^{\mathrm{ice}}\right.$ in $\mathrm{Pa}$ ). For the ice nucleation $50 \%$ $\mathrm{H}_{2} \mathrm{O}$ supersaturation is assumed to be necessary (Tabazadeh et al., 1997; Peter and Grooß, 2012).

With the help of $\mathrm{H}_{2} \mathrm{O}$ (ice) the total mass of ice particles $\left(m_{\text {ice }}\right)$ as well as their total volume $\left(V_{\text {ice }}\right.$ in $\left.\mathrm{m}^{3}\right)$ is calculated. The total number density $\left(N_{\text {ice }}\right)$ and the mean radius $\left(r_{\text {ice }}\right)$ of ice particles is calculated with the help of a minimum ice radius $\left(r_{\min }\right)$ and a maximum number density of ice particles $\left(N_{\max }\right)$. In our simulations we assumed for $r_{\min }=1 \times 10^{-5} \mathrm{~cm}$ and for $N_{\max }=0.042 \mathrm{~cm}^{-3}$ (Höpfner et al., 2006).

With $N_{\text {ice }}$ and $r_{\text {ice }}$ it is possible to calculate the surface area density of ice ( $\left.A_{\text {ice }}\right)$, which is important for the calculation of the heterogeneous reaction rates on ice particles.

There are two parameterisations for the formation of NAT particles included in the PSC submodel. It is possible to choose either a "thermodynamical NAT parameterisation", assuming instantaneous thermodynamical equilibrium (Han- son and Mauersberger, 1988), or the new "kinetic growth NAT parameterisation", based on the efficient growth and sedimentation algorithm of Carslaw et al. (2002) and van den Broek et al. (2004) implemented into the submodel by Kirner et al. (2011). In both cases, NAT formation takes place below the NAT existence temperature ( $T_{\mathrm{NAT}}$, depending on the pressure and on the partial pressures of $\mathrm{HNO}_{3}$ and $\mathrm{H}_{2} \mathrm{O}$ ) with the assumption of a necessary super cooling of $3 \mathrm{~K}$ (Schlager and Arnold, 1990; Dye et al., 1992).

We used the kinetic growth NAT parameterisation for this study. Hence, also homogeneous NAT nucleation is possible in our simulations.

The time-related growth of the NAT particles in the kinetic growth NAT parameterisation is based on the calculation of the surface growth factor $\left(\mathrm{G}\right.$ in $\left.\mathrm{m}^{2} \mathrm{~s}^{-1}\right)$ :

$G=\frac{D_{\mathrm{HNO}_{3}}^{*} M_{\mathrm{NAT}}}{\rho_{\mathrm{NAT}} R_{\mathrm{gas}} T}\left(e_{\mathrm{HNO}_{3}}-E_{\mathrm{HNO}_{3}}^{\mathrm{NAT}}\right)$

$G$ is depending on the temperature ( $T$ in $\mathrm{K}$ ), the difference between the partial $\mathrm{HNO}_{3}$ vapour pressure $\left(e_{\mathrm{HNO}_{3}}\right.$ in $\left.\mathrm{Pa}\right)$ and the saturation vapour pressure of $\mathrm{HNO}_{3}$ over NAT $\left(E_{\mathrm{HNO}_{3}}\right.$ in $\mathrm{Pa}$ ), as well as on the diffusion coefficient of $\mathrm{HNO}_{3}$ in

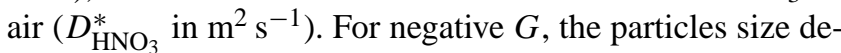
creases through evaporation.

With the help of this surface growth factor it is possible to simulate the growth of NAT particles. For integration of this growth concept in EMAC, which is an Eulerian model, it is necessary to split the NAT particles into different size bins. In the kinetic growth NAT parameterisation of the submodel PSC, a separation into eight size bins is consequently implemented (see Table 1). The minimum and maximum NAT radii in the different size bins, as well the maxima of the NAT number densities are assumed based on Fahey et al. (2001).

The total number density of NAT $\left(N_{\mathrm{NAT}}\right)$ is calculated as the sum over all eight size bins. The mean NAT radius $\left(r_{\mathrm{NAT}}\right)$ is calculated from the NAT radii of each size bin, weighted with the corresponding NAT number density. With $N_{\mathrm{NAT}}$ and $r_{\text {NAT }}$ it is possible to calculate the surface area density of NAT $\left(A_{\mathrm{NAT}}\right)$, which is important for the calculation of the heterogeneous reaction rates on NAT particles.

A comprehensive description of the submodel PSC is given by Kirner et al. (2011). 
Table 2. The four performed EMAC simulations with different assumptions for heterogeneous chemistry.

\begin{tabular}{lll}
\hline Simulations & Time period & Heterogeneous chemistry \\
\hline Standard & $2000-2012$ & on liquid, NAT and ice particles \\
NoHet & $2005-2012$ & none \\
Liquid & $2005-2012$ & on liquid particles \\
LiquidNAT & $2005-2012$ & on liquid and NAT particles \\
\hline
\end{tabular}

\section{Performed simulations}

Four different EMAC simulations were performed using the submodel PSC: a standard simulation (Standard) from 2000 to 2012 with heterogeneous chemistry on liquid, NAT and ice particles and three additional sensitivity simulations from 2005 to 2012. In the three sensitivity simulations, we only changed the heterogeneous chemistry on PSC particles by switching the chemistry on liquid, NAT and ice particles on and off. We performed one sensitivity simulation without heterogeneous chemistry (NoHet), one sensitivity simulation with heterogeneous chemistry only on liquid particles (Liquid) and one sensitivity simulation with heterogeneous chemistry only on liquid and NAT particles, but excluding heterogeneous chemistry on ice particles (LiquidNAT) (see also Table 2).

Assumptions on the formation and distribution of the PSC particles are the same for the four simulations. Also the denitrification caused by the sedimentation of NAT particles is simulated in all simulations consistently. Only the assumptions regarding the heterogeneous chemistry on liquid, NAT and ice particles are different.

Through the assumptions made here in the sensitivity simulations we only test the impact of the heterogeneous reactivity of the different PSC particle types. An alternative scenario would be to make assumptions on the formation of PSC (especially NAT) and test the combined effect of heterogenous chemistry and particle setting.

The chemistry of the standard simulation is initialised from a previously completed climatological simulation, the meteorological conditions from ERA-Interim reanalysis. For initialization of the three sensitivity simulations the rerun files of the standard simulation are used. Boundary conditions for greenhouse gases are in all four EMAC simulations from the IPCC-A1B scenario (IPCC, 2007). Boundary conditions for ozone depleting substances (CFCs and halons) are from the WMO-Ab scenario (WMO, 2007). We increased the $\mathrm{CH}_{3} \mathrm{Br}$ boundary condition by a constant value of $5 \mathrm{pptv}$ (WMO, 2007), because very short lived bromine species are not included in our simulations.

The simulation includes a comprehensive chemistry setup with 104 gas phase species, 234 gas phase reactions, 67 photolysis reactions, and 11 heterogeneous reactions on liquid aerosols, NAT and ice particles (Jöckel et al., 2006).

\section{The MLS observations}

The Earth Observing System (EOS) Microwave Limb Sounder (MLS) (Waters et al., 2006) onboard NASA's Aura satellite launched on 15 July 2004. It observes in a sunsynchronous orbit $\left(98^{\circ}\right.$ inclination) temperature and trace gas profiles between $82^{\circ} \mathrm{S}$ and $82^{\circ} \mathrm{N}$ by scanning the Earth's limb and measuring the microwave emission. The MLS vertical resolution depends on the considered species and usually ranges between $3-4 \mathrm{~km}$ in troposphere/stratosphere and $8 \mathrm{~km}$ in the mesosphere (Livesey et al., 2011).

In this study we are using MLS Level-2 data (Version 3.3) to evaluate $\mathrm{HNO}_{3}, \mathrm{ClO}$, and $\mathrm{O}_{3}$. In the stratosphere the precision of the $\mathrm{HNO}_{3}$ profile is about $0.7 \mathrm{ppbv}$ with a vertical resolution between 3 to $5 \mathrm{~km}$ (Sect. 3.11, Livesey et al., 2011). The precision of $\mathrm{ClO}$ is between 0.1 and $0.3 \mathrm{ppbv}$ with a vertical resolution between 3 to $5 \mathrm{~km}$. (Santee et al., 2008). In the uppermost troposphere and stratosphere the precision of MLS $\mathrm{O}_{3}$ data is between 0.04 and $0.5 \mathrm{ppm}$ with a vertical resolution of about $3 \mathrm{~km}$ (Froidevaux et al., 2008).

For comparison with the EMAC results we analysed the MLS observations of the year 2007 (Figs. 1, 4, and 6).

\section{Mean development of liquid, NAT and ice particles in EMAC and simulated denitrification}

The formation and distribution of PSCs are simulated in EMAC very reasonably. For example, in Fig. 1 (first to third row) the simulated denitrification in $46 \mathrm{hPa}$ due to NAT particles from the standard simulation is presented. After the temperature has dropped below $192 \mathrm{~K}$, and thus the necessary temperature threshold is reached for NAT formation, the first NAT particles are formed on 12 May 2007 over Antarctica. Due to the continued cooling from 12 May 2007 to 31 May 2007 the number density of NAT increases to $2.4 \times 10^{-4} \mathrm{~cm}^{-3}$. Simultaneously, the NAT PSCs are expanding into a larger area. The first hint of denitrification due to sedimentation of NAT is visible on 19 May 2007. Ongoing NAT formation and sedimentation of NAT particles leads in EMAC to reduced $\mathrm{HNO}_{3}$ in the area in which NAT particles are present.

The MLS measurements of $\mathrm{HNO}_{3}$ in $46 \mathrm{hPa}$ (Fig. 1, bottom row) show almost the same spatial and temporal evolution of denitrification as in the EMAC simulation. The MLS $\mathrm{HNO}_{3}$ mixing ratios are in general higher than simulated in EMAC, but the first hint of denitrification occurs about at the same time as in the standard simulation and the time development of $\mathrm{HNO}_{3}$ is similar.

In addition to NAT particles, also ice particles and liquid particles are calculated with the submodel PSC. In Fig. 2 the time development of liquid particles, NAT and ice particles is shown as an average over the latitudes from $80^{\circ} \mathrm{S}$ to $90^{\circ} \mathrm{S}$ and over the 5 years from 2005 to 2009 . The results shown in Fig. 2 are valid for the standard and for all three 


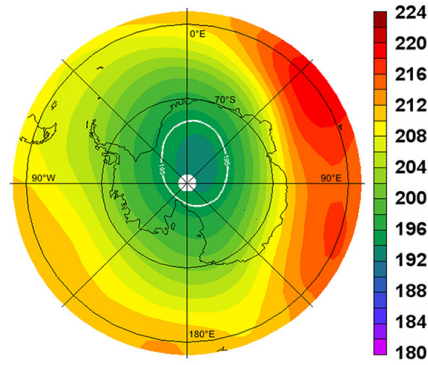

Temp. [K] 46 hPa - 12.05.2007

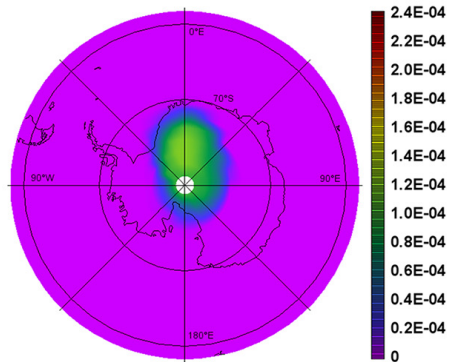

N_NAT [1/cm3] $46 \mathrm{hPa}-12.05 .2007$

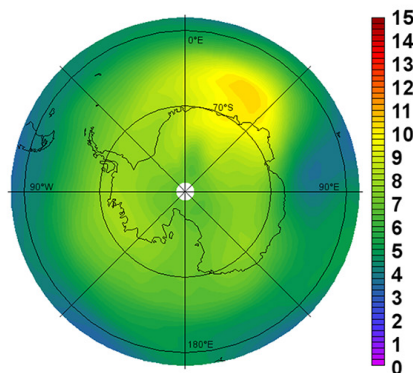

HNO3 [ppbv] 46 hPa - 12.05.2007

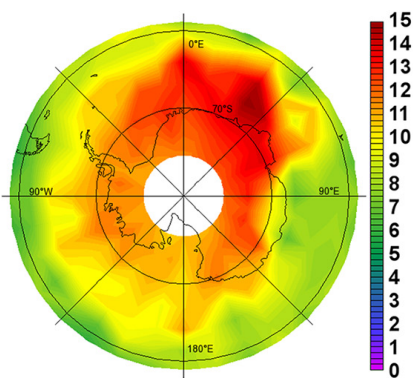

HNO3 [ppbv] $46 \mathrm{hPa}-12.05 .2007$

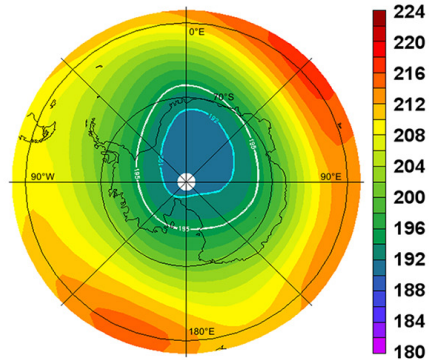

Temp. [K] 46 hPa - 19.05.2007

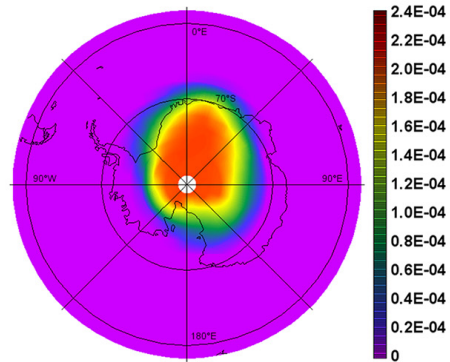

N_NAT [1/cm3] 46 hPa - 19.05.2007

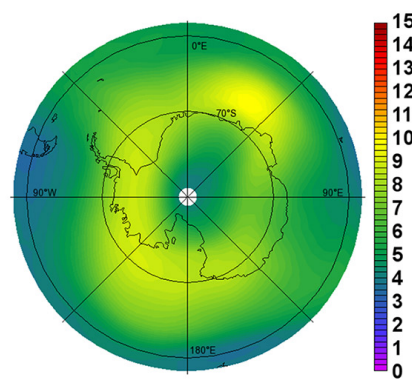

HNO3 [ppbv] 46 hPa - 19.05.2007

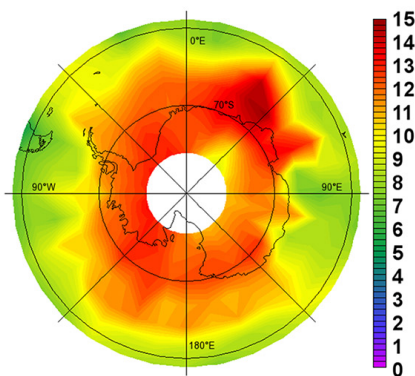

HNO3 [ppbv] 46 hPa - 19.05.2007

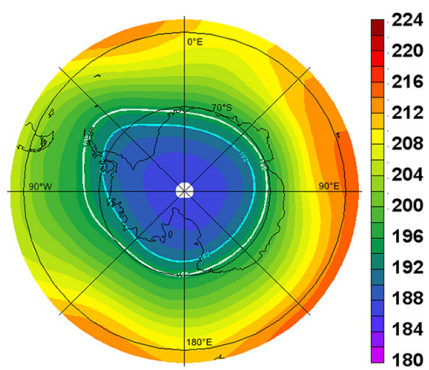

Temp [K] $46 \mathrm{hPa}-\mathbf{3 1 . 0 5 . 2 0 0 7}$

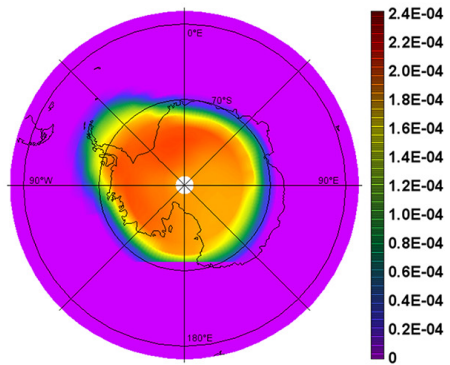

N_NAT [1/cm3] 46 hPa - 31.05.2007

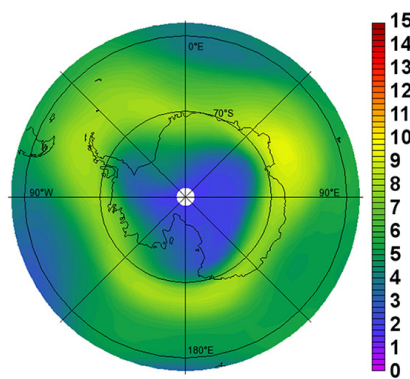

HNO3 [ppbv] 46 hPa - 31.05.2007

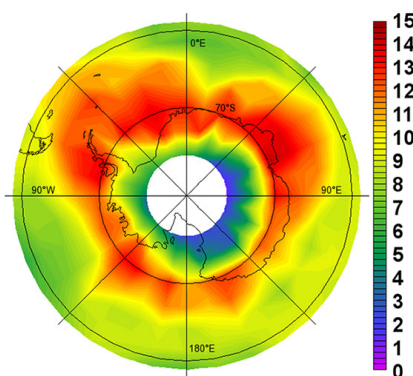

HNO3 [ppbv] 46 hPa - 31.05.2007

Figure 1. Denitrification in the standard simulation and from MLS - time series of simulated temperature in K (top row) and the simulated distribution of $N_{\mathrm{NAT}}$ in $\mathrm{cm}^{-3}$ (second row) and $\mathrm{HNO}_{3}$ in ppbv from EMAC (third row) and $\mathrm{HNO}_{3}$ in ppbv from MLS (bottom row) for southern polar latitudes on $46 \mathrm{hPa}$ approximately $21.6 \mathrm{~km}$ ) for the dates 12 May 2007, 19 May 2007, and 31 May 2007. In the temperature plots the isotherms of $195 \mathrm{~K}$ (white) and $192 \mathrm{~K}$ (light blue) are marked.

sensitivity simulations, i.e. the formation and development of stratospheric aerosol and PSCs are identical for all simulations. NAT is visible from mid-May until October in the EMAC simulations. The relatively slow increase of the num- ber density to values of more than $2 \times 10^{-4} \mathrm{~cm}^{-3}$ by end of May is caused by differences in the timing of the first NAT appearances in the individual years of 2005 to 2009 . The decrease of NAT number densities between June to Septem- 

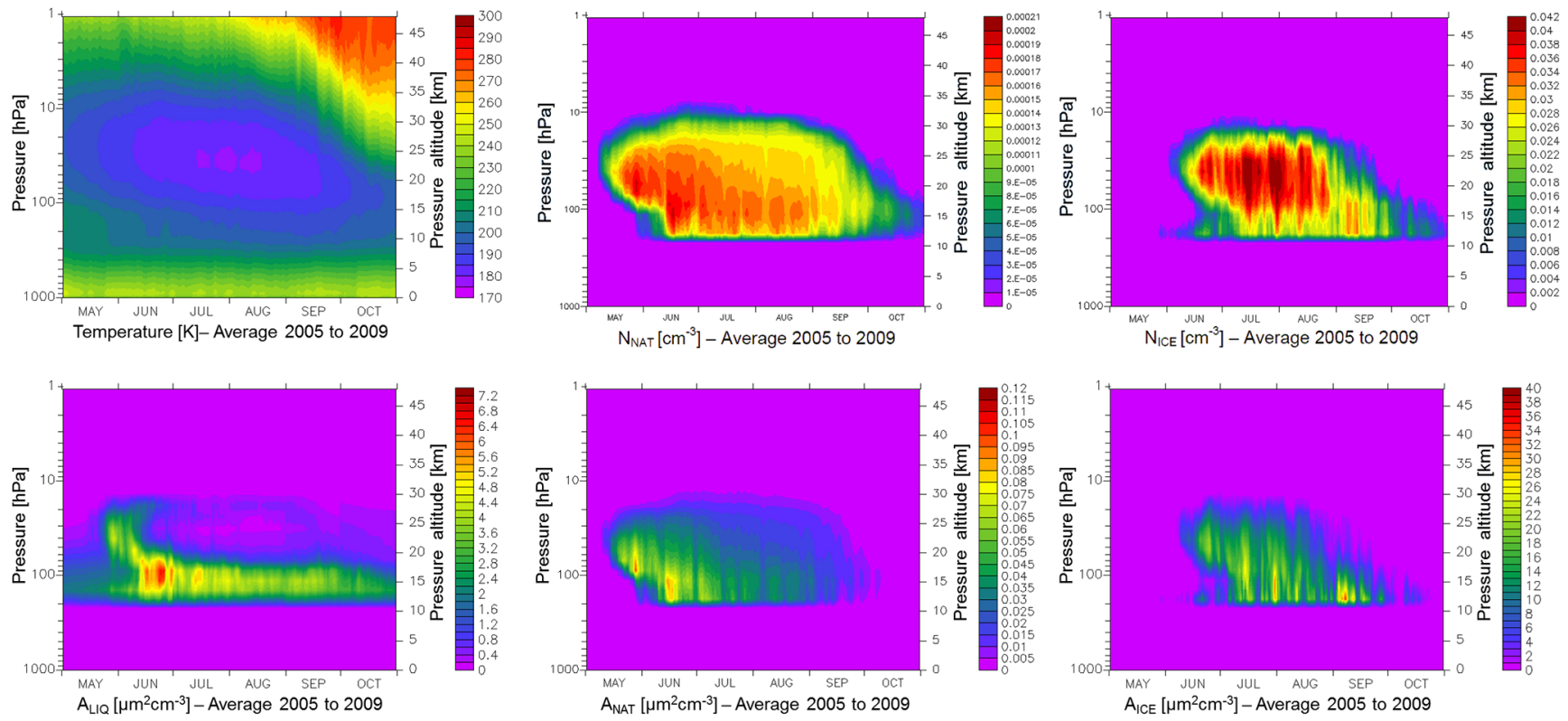

Figure 2. Stratospheric temperature, liquid and solid particles - time series averaged from $80^{\circ}$ to $90^{\circ} \mathrm{S}$ and over the years 2005 to 2009 for temperature in K (top left), number densities of NAT $\left(N_{\mathrm{NAT}}\right)$ and ice particles $\left(N_{\text {ice }}\right)$ in $\mathrm{cm}^{-3}$ (top centre and right), as well as surface area densities of liquid particles $\left(A_{\text {liq }}\right)$, NAT $\left(A_{\mathrm{NAT}}\right)$ and ice particles $\left(A_{\text {ice }}\right)$ in $\mu \mathrm{m}^{2} \mathrm{~cm}^{-3}$ (bottom left to right). The results shown are valid for the standard and for all three sensitivity simulations.

ber is caused by the sedimentation of larger NAT particles and the related denitrification. Ice particles exist mainly from June to September with mean maxima of number densities of over $0.04 \mathrm{~cm}^{-3}$. In comparison to liquid and NAT particles they have the largest surface area densities with values up to $38 \mu \mathrm{m}^{2} \mathrm{~cm}^{-3}$. The liquid particles have the second largest surface area densities with values up to $6.8 \mu \mathrm{m}^{2} \mathrm{~cm}^{-3}$, the NAT particles the smallest with maxima of $0.11 \mu \mathrm{m}^{2} \mathrm{~cm}^{-3}$.

\section{Contribution of NAT, ice and liquid particles to stratospheric chlorine activation and ozone depletion}

The contribution of heterogeneous reactions on liquid, NAT and ice particles to chlorine activation and the corresponding ozone depletion in polar spring is determined by comparing the standard and the sensitivity simulations. The impact of the liquid particles is assessed by subtracting the results of the simulation NoHet from the results of the simulation Liquid. The absolute contribution of additional NAT chemistry is calculated by subtracting the results of the simulation Liquid from the simulation LiquidNAT, and the contribution of additional heterogeneous chemistry on ice particles by subtracting the results of the simulation LiquidNAT from the simulation Standard.

In Figs. 3 to 7 we examine the chlorine activation and ozone depletion of the different EMAC simulations and compare the results of the standard simulation with MLS observations. For a better statistics we averaged the simulated $\mathrm{ClO}_{\mathrm{x}}$ and $\mathrm{O}_{3}$ results from EMAC over the southern high latitudes from $80^{\circ} \mathrm{S}$ to $90^{\circ} \mathrm{S}$ and over the 5 -year time period from 2005 to 2009 (Figs. 3 and 5) and the ozone columns as zonal mean over the same 5 years (Fig. 7). For the comparison of the EMAC results with MLS observations the year 2007 is chosen (Figs. 4 and 6).

In Fig. 3, the evolution of $\mathrm{ClO}_{\mathrm{x}}$ in the standard simulation and the contributions of liquid, NAT and ice particles are shown. It is obvious that the simulated $\mathrm{ClO}_{\mathrm{x}}$ development with maximum values of about $2.9 \mathrm{ppbv}$ is mainly caused by the heterogeneous chemistry on liquid particles with contributions up to $2.6 \mathrm{ppbv}$. There is almost no extra chlorine activation due to the additional heterogeneous chemistry on NAT particles with a contribution below $0.1 \mathrm{ppbv}$ and only a slight additional chlorine activation due to heterogeneous chemistry on ice particles. Ice particles only show a relevant contribution in the upper PSC region in which only few liquid particles are simulated (see Fig. 2). A maximum of about $0.33 \mathrm{ppbv}$ additional $\mathrm{ClO}_{\mathrm{x}}$ is present in the region between 10 and $30 \mathrm{hPa}$ from end of June until mid-September due to additional heterogeneous chemistry on ice.

Liquid particles contribute more than $90 \%$ to chlorine activation for most of the time in Antarctic winter and spring in the performed EMAC simulations. The contribution is almost $100 \%$ from June to August in the region between $30 \mathrm{hPa}$ and $100 \mathrm{hPa}$. The heterogeneous chemistry of additional ice particles is only relevant in the upper PSC region, as mentioned above, with maximum contributions in the range of $10 \%$ to $15 \%$ of the total chlorine activation. The NAT particles show only a relevant contribution to chlo- 

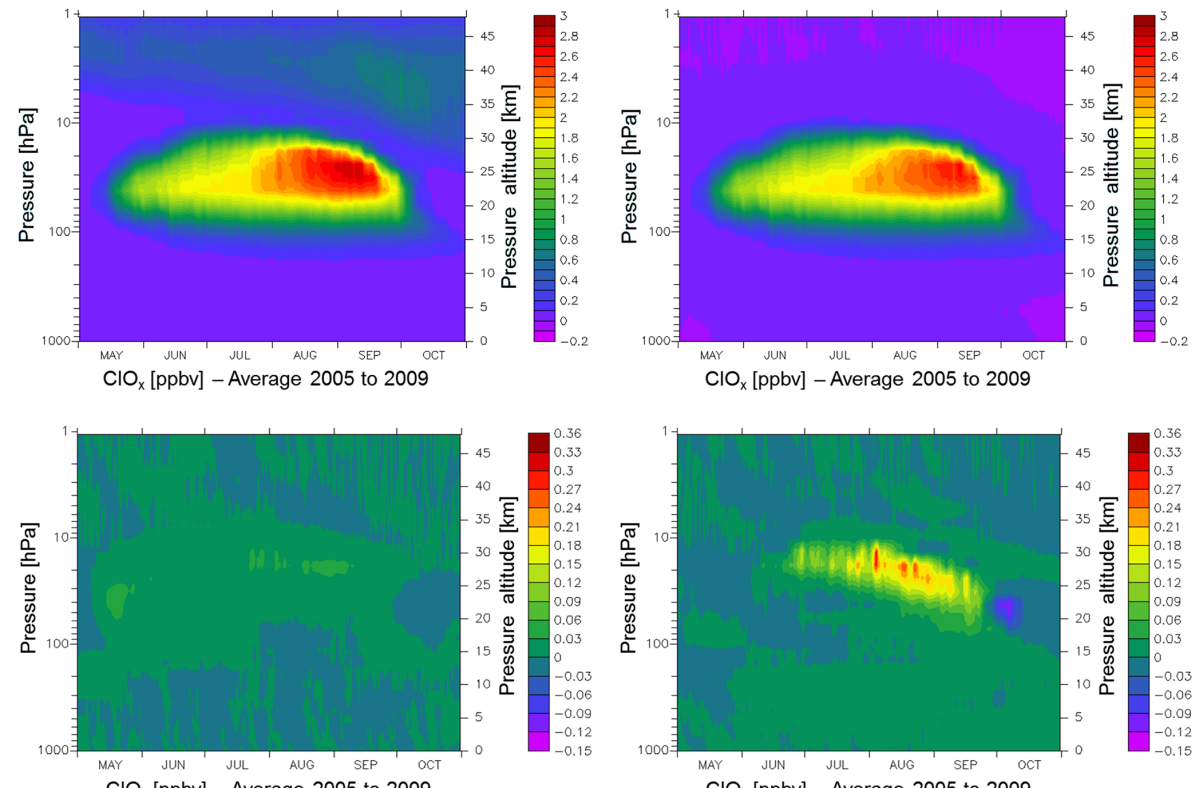

Figure 3. Chlorine activation - time series of $\mathrm{ClO}_{\mathrm{x}}$ in ppbv in the standard simulation during Antarctic winter and spring averaged over $80^{\circ}$ to $90^{\circ} \mathrm{S}$ and the years 2005 to 2009 (top left) and contribution of liquid particles (top right), additional contribution by activation on NAT particles (bottom left) and additional contribution by activation on ice particles (bottom right). $\mathrm{ClO}_{\mathrm{x}}$ is defined as the sum of $\mathrm{ClO}+\mathrm{OClO}+\mathrm{HOCl}+2 \mathrm{Cl}_{2}+2 \mathrm{Cl}_{2} \mathrm{O}_{2}$. Note that the colour bars have different units.
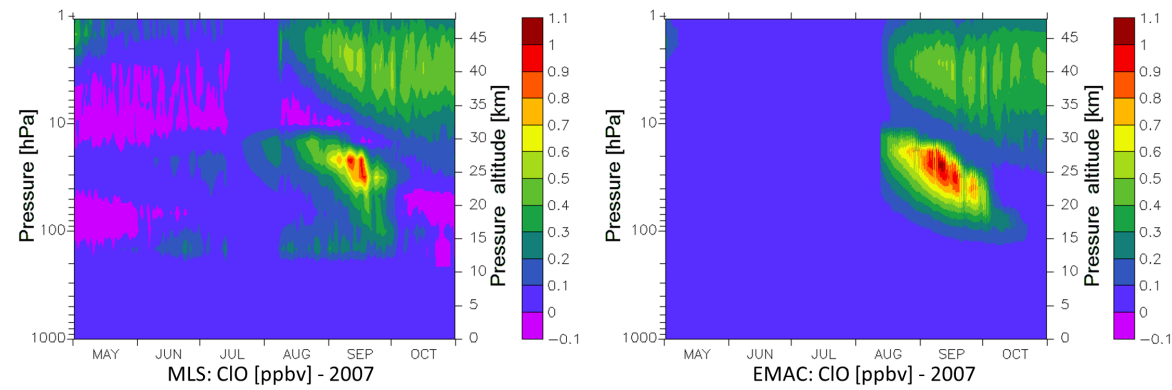

Figure 4. Comparison of $\mathrm{ClO}$ from EMAC with MLS observations - time series of $\mathrm{ClO}$ in ppbv from MLS (left) and from the standard EMAC simulation (right) during Antarctic winter and spring of 2007 in $79.5^{\circ} \mathrm{S}$.

rine activation during the initial PSC occurrence in mid-May in the region between $20 \mathrm{hPa}$ and $50 \mathrm{hPa}$, with contributions of up to $10 \%$.

The MLS measurements of $\mathrm{ClO}$ in $79.5^{\circ} \mathrm{S}$ in Antarctic winter and spring (Fig. 4) compare well with the $\mathrm{ClO}$ development of the EMAC standard simulation. In EMAC and MLS increased $\mathrm{ClO}$ mixing ratios are visible between midAugust and end of September in the middle and upper stratosphere. In the middle stratosphere maximum values over $1 \mathrm{ppbv}$ are reached in early September both in the measurements and in the simulation. In the upper stratosphere the simulated $\mathrm{ClO}$ development is also close to the MLS observations.

The evolution of ozone in the different EMAC simulations is shown in Fig. 5. The ozone depletion is highest from mid-
September to late October, resulting in the formation of the ozone hole (e.g. Grooß et al., 2011). The largest contribution to the ozone depletion comes from chlorine activated on liquid particles with values of more than 2500 ppbv. In contrast, the contribution that can be attributed to additional chemistry on ice particles reaches values of only $170 \mathrm{ppbv}$ in the upper PSC region between 10 to $30 \mathrm{hPa}$. A contribution of NAT particles is visible in the region between 20 to $40 \mathrm{hPa}$ in September and October, but the values are close to zero.

The comparison of the EMAC ozone evolution with MLS in $79.5^{\circ} \mathrm{S}$ in Antarctic winter and spring (Fig. 6) is very reasonable. The observed ozone hole is represented in EMAC, even if the $\mathrm{O}_{3}$ decrease is slightly smaller than in MLS. In general, the $\mathrm{O}_{3}$ mixing ratios are slightly higher in EMAC 

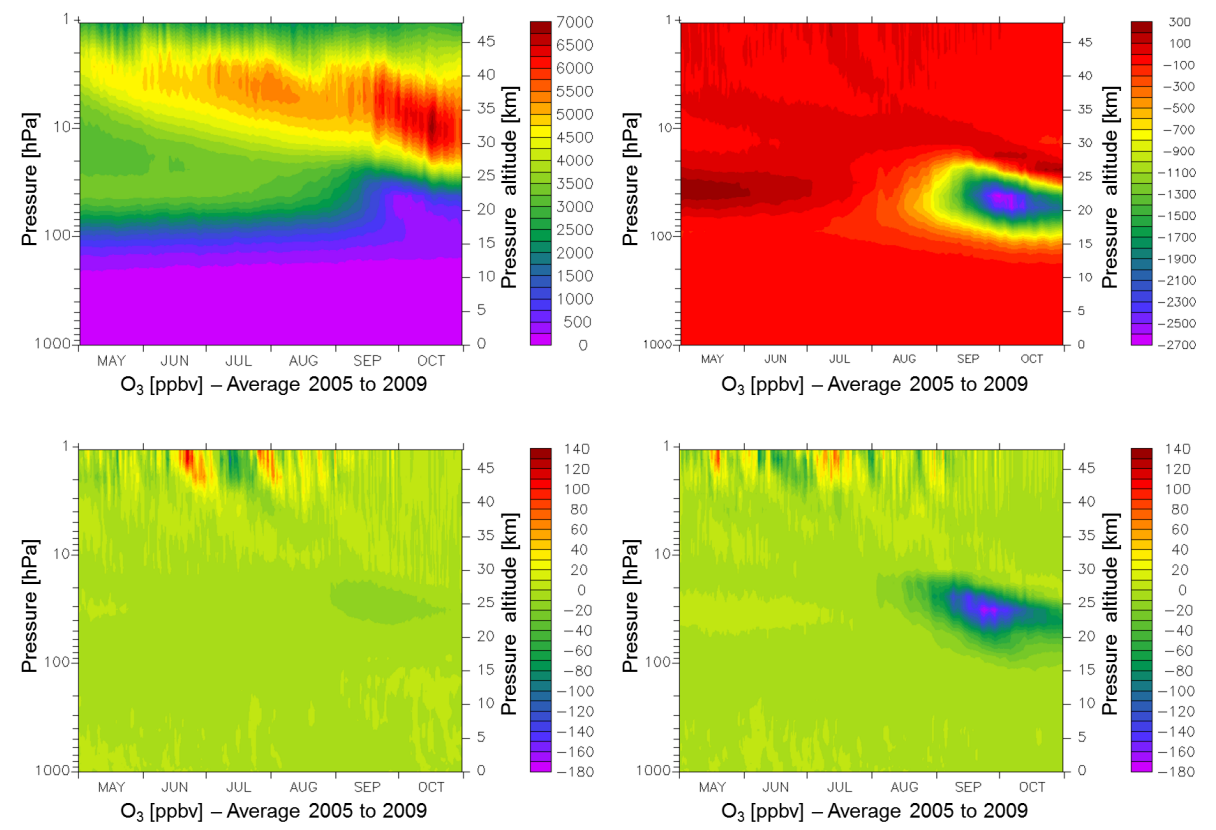

Figure 5. Ozone depletion - time series of $\mathrm{O}_{3}$ in ppbv in the standard EMAC simulation during Antarctic winter and spring averaged over $80^{\circ}$ to $90^{\circ} \mathrm{S}$ and the years 2005 to 2009 (top left) and contribution of liquid particles (top right), additional NAT particles (bottom left) and additional ice particles (bottom right). Note that the colour bars have different units.
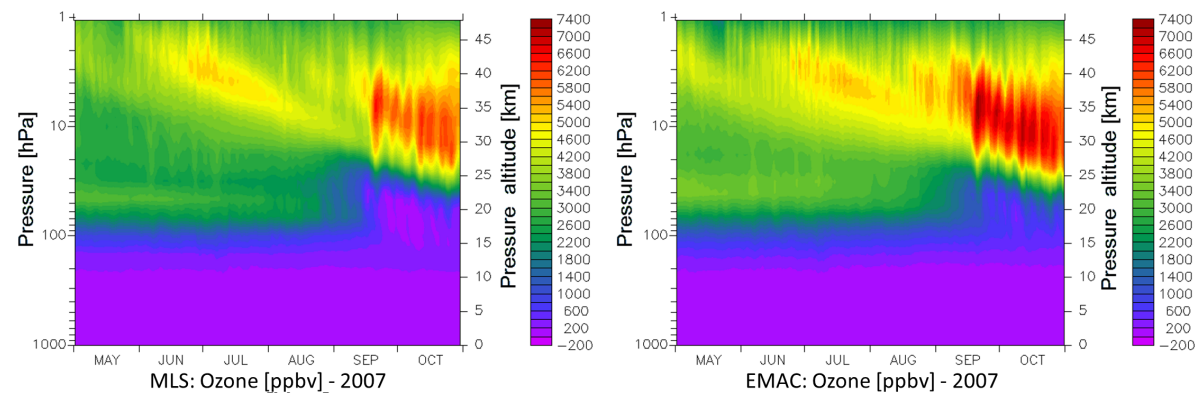

Figure 6. Comparison of $\mathrm{O}_{3}$ from EMAC with MLS observations - time series of $\mathrm{O}_{3}$ in ppbv from MLS (left) and from the standard EMAC simulation (right) during Antarctic winter and spring of 2007 in $79.5^{\circ} \mathrm{S}$.

than in the observations, but the time evolution of $\mathrm{O}_{3}$ agree closely with MLS.

Figure 7 shows the total effect that heterogeneous chemistry on different PSC particles has on the time development of the ozone column. The ozone column shows a decrease of more than $130 \mathrm{DU}$ by early October in high southern latitudes. Chlorine activation on liquid particles is mainly responsible for this decrease. The contribution of liquid particles to the simulated ozone depletion is at least $95 \%$ during September to October at southern high latitudes.

The contribution of additional heterogeneous chemistry on ice particles to Antarctic ozone depletion only reaches $5 \mathrm{DU}$ and is always less than $5 \%$. The contribution of additional heterogeneous chemistry on NAT particles is less than $0.5 \mathrm{DU}$ and thus almost negligible. On the other hand, the NAT particles are essential for the denitrification in polar spring and thus have an additional indirect influence on the formation of the ozone hole.

\section{Conclusions}

The significance of heterogeneous reactions on NAT and ice particles with respect to chlorine activation and ozone depletion in Antarctic winter and spring is small compared to reactions on liquid particles in our simulations performed with the EMAC model. The simulated heterogeneous chemistry on liquid particles is sufficient to activate at least about $90 \%$ of the chlorine.

Liquid particles alone are sufficient to activate almost all of the available chlorine, with the exception of the upper PSC regions between 10 and $30 \mathrm{hPa}$, where temporarily ice par- 

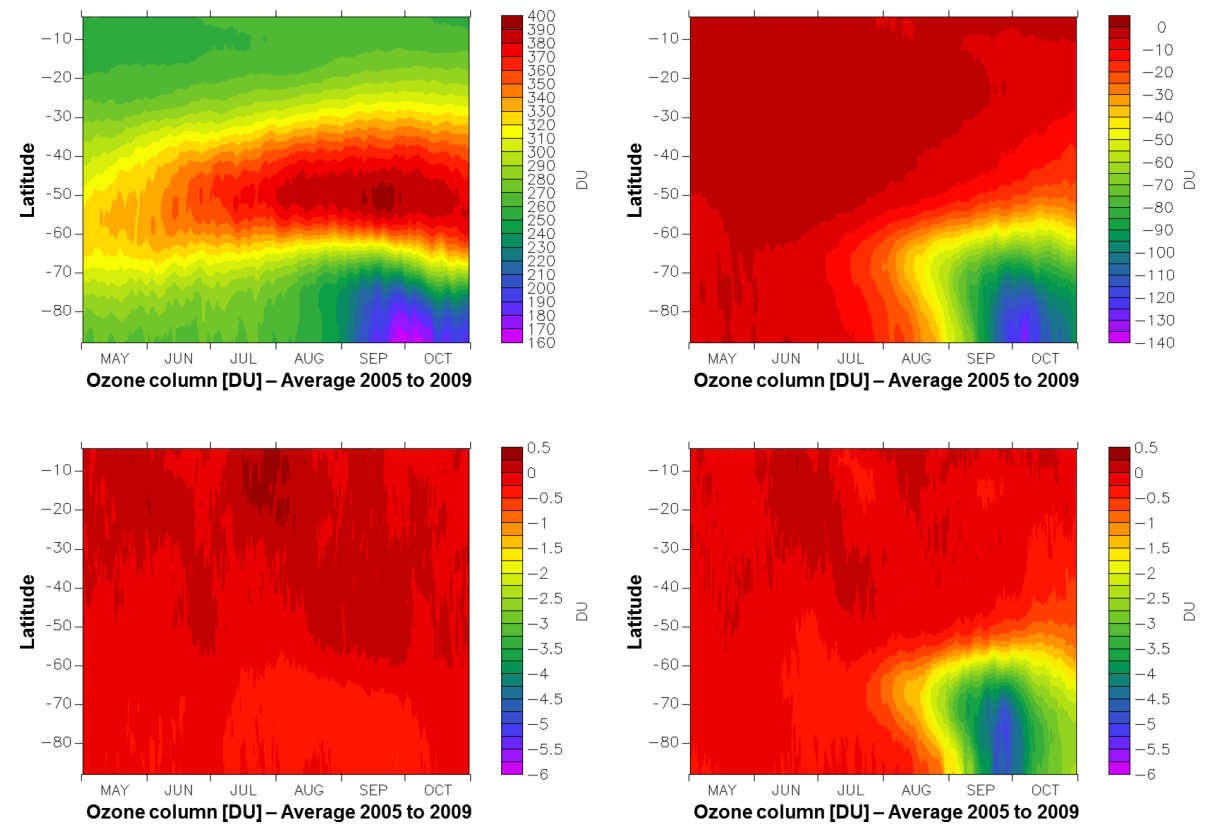

Figure 7. Ozone columns - development of ozone column in DU in the standard simulation during Antarctic winter and spring in the Southern Hemisphere averaged over the years 2005 to 2009 (top left) and contribution of liquid particles (top right), additional NAT particles (bottom left) and additional ice particles (bottom right) to ozone depletion. Note that the colour bars have different units.

ticles show a relevant contribution when few other types of PSCs are present. Shortly after the first PSC occurrence, NAT particles contribute a very small fraction to chlorine activation.

Heterogeneous chemistry on liquid particles is mainly responsible for the ozone depletion in polar spring in our EMAC simulations. In high southern latitudes heterogenous chemistry on ice particles causes only up to $5 \mathrm{DU}$ of additional ozone depletion in the column and heterogeneous chemistry on NAT particles less than $0.5 \mathrm{DU}$.

It might be surprising that the enormous increase of heterogeneous reactivity provided by the frequent occurrence of ice PSCs has rather little impact on chlorine activation in the simulations presented here. However, a stronger heterogeneous reactivity does not necessarily translate into stronger chlorine activation. Frequently, chlorine activation through heterogeneous chemistry is rate limited by the gas phase formation of reaction partners for heterogeneous reactions (e.g. Crutzen et al., 1992; Müller et al., 1994). This is in particular true for the time period after the initial activation step, when $\mathrm{HCl}$ and $\mathrm{ClONO}_{2}$ are titrated against each other on the first occurrence of heterogeneous reactivity when temperatures sink below the threshold for chlorine activation. If under such circumstances, likely in polar night, ice particles form days or weeks after the initial activation step, they will have very little impact on chlorine activation.

The MLS measurements of $\mathrm{HNO}_{3}, \mathrm{ClO}$ and $\mathrm{O}_{3}$ in Antarctic winter and spring of 2007 are close to the EMAC simulations. The observed time evolution of these three substances is represented very reasonably in EMAC, even though the $\mathrm{HNO}_{3}$ mixing ratios are slightly smaller and the $\mathrm{O}_{3}$ mixing ratios slightly higher than in MLS.

An open question that remains is the influence of our assumed NAT number densities and size distribution based on Fahey et al. (2001). In other studies (e.g. Northway et al., 2002; Voigt et al., 2005; Pitts et al., 2011) different NAT number densities and particle size distributions are observed. But the current estimates of NAT number densities are rather low and in the range of Fahey et al. (2001). In comparison to the surface area densities of liquid particles and ice particles the NAT surface area densities are low in all studies. Therefore, the influence of the assumed NAT number densities and size distribution should be small.

Here, we have confirmed the dominant role of liquid particles to polar chlorine activation for Antarctic conditions. This finding should be taken into account in studies of future polar ozone development when the stratospheric halogen loading declines. Regarding the future polar ozone evolution it will be crucial how strong the future cooling in the lower and middle stratosphere will be in polar winters and how strong this will affect the occurrence and heterogeneous reactivity of PSCs (e.g. Butchart et al., 2010; Bohlinger et al., 2014). The future increase of the background stratospheric aerosol, as discussed by Solomon et al. (2011), could also lead to an altered distribution of liquid particles with implications for the polar chlorine activation. 
Acknowledgements. We acknowledge support by Deutsche Forschungsgemeinschaft and Open Access Publishing Fund of Karlsruhe Institute of Technology. We thank the MLS team for providing us their data. This MLS data were acquired as part of the activities of NASA's Science Mission Directorate, and are archived and distributed by the Goddard Earth Sciences (GES) Data and Information Services Center (DISC).

The service charges for this open-access publication have been covered by a Research Centre of the Helmholtz Association.

Edited by: M. Palm

\section{References}

Abbatt, J. P. D. and Molina, M. J.: Heterogeneous interactions of $\mathrm{ClONO}_{2}$ and $\mathrm{HCl}$ on nitric acid trihydrate at $202 \mathrm{~K}$, J. Phys. Chem., 96, 7674-7679, doi:10.1021/j100198a036, 1992.

Atkinson, R., Baulch, D. L., Cox, R. A., Crowley, J. N., Hampson, R. F., Hynes, R. G., Jenkin, M. E., Rossi, M. J., and Troe, J.: Evaluated kinetic and photochemical data for atmospheric chemistry: Volume III gas phase reactions of inorganic halogens, Atmos. Chem. Phys., 7, 981-1191, doi:10.5194/acp-7-981-2007, 2007.

Bohlinger, P., Sinnhuber, B.-M., Ruhnke, R., and Kirner, O.: Radiative and dynamical contributions to past and future Arctic stratospheric temperature trends, Atmos. Chem. Phys., 14, 1679-1688, doi:10.5194/acp-14-1679-2014, 2014.

Buchholz, J.: Simulations of physics and chemistry of polar stratospheric clouds with a general circulation model, Ph.D. thesis, Johannes Gutenberg University Mainz, 2005.

Butchart, N., Cionni, I., Eyring, V., Shepherd, T. G., Waugh, D. W., Akiyoshi, H., Austin, J., Brühl, C., Chipperfield, M. P., Cordero, E., Dameris, M., Deckert, R., Dhomse, S., Frith, S. M., Garcia, R. R., Gettelman, A., Giorgetta, M. A., Kinnison, D. E., Li, F., Mancini, E., McLandress, C., Pawson, S., Pitari, G., Plummer, D. A., Rozanov, E., Sassi, F., Scinocca, J. F., Shibata, K., and Tian, W.: Chemistry-climate model simulations of 21 st century stratospheric climate and circulation changes, J. Climate, 23, 53495374, doi:10.1175/2010JCLI3404.1, 2010.

Carslaw, K. S., Luo, B., and Peter, T.: An analytic expression for the composition of aqueous $\mathrm{HNO}_{3}-\mathrm{H}_{2} \mathrm{SO}_{4}$ stratospheric aerosols including gas phase removal of $\mathrm{HNO}_{3}$, Geophys. Res. Lett., 22, 14, 1877-1880, doi:10.1029/95GL01668, 1995.

Carslaw, K. S. and Peter, T.: Uncertainties in reactive uptake coefficients for solid stratospheric particles -1 . Surface chemistry, Geophys. Res. Lett., 24, 1743-1746, 1997.

Carslaw, K. S., Peter, T., and Müller, R.: Uncertainties in Reactive Uptake Coefficients for Solid Stratospheric Particles - 2. Effect on Ozone Depletion, Geophys. Res. Lett., 24, 1747-1750, 1997.

Carslaw, K. S., Kettleborough, J. A., Northway, M. J., Davies, S., Gao, R. S., Fahey, D. W., Baumgardner, D. G., Chipperfield, M. P., and Kleinböhl, A.: A vortex-scale simulation of the growth and sedimentation of large nitric acid hydrate particles, J. Geophys. Res., 107, 8300, doi:10.1029/2001JD000467, 2002.

Crutzen, P. J., Müller, R., Brühl, C., and Peter, T.: On the potential importance of the gas-phase reaction $\mathrm{CH}_{3} \mathrm{O}_{2}+\mathrm{ClO} \rightarrow \mathrm{ClOO}$
$+\mathrm{CH}_{3} \mathrm{O}$ and the heterogeneous reaction $\mathrm{HOCl}+\mathrm{HCl} \rightarrow \mathrm{H}_{2} \mathrm{O}$ $+\mathrm{Cl}_{2}$ in ozone hole chemistry, Geophys. Res. Lett., 19, 11131116, doi:10.1029/92GL01172, 1992.

Dee, D. P., Uppala, S. M., Simmons, A. J., Berrisford, P., Poli, P., Kobayashi, S., Andrae, U., Balmaseda, M. A., Balsamo, G., Bauer, P., Bechtold, P., Beljaars, A. C. M., van de Berg, L., Bidlot, J., Bormann, N., Delsol, C., Dragani, R., Fuentes, M., Geer, A. J., Haimberger, L., Healy, S. B., Hersbach, H., Hólm, E. V., Isaksen, L., Kållberg, P., Köhler, M., Matricardi, M., McNally, A. P., Monge-Sanz, B. M., Morcrette, J.-J., Park, B.-K., Peubey, C., de Rosnay, P., Tavolato, C., Thépaut, J.-N. and Vitart, F.: The ERA-Interim reanalysis: configuration and performance of the data assimilation system, Q. J. R. Meteorol. Soc., 137, 553-597, doi:10.1002/qj.828, 2011.

Drdla, K. and Müller, R.: Temperature thresholds for chlorine activation and ozone loss in the polar stratosphere, Ann. Geophys., 30, 1055-1073, doi:10.5194/angeo-30-1055-2012, 2012.

Dye, J. E., Baumgardener, D., Gandrud, B. W., Kawa, S. A., Kelly, K. K., Lowenstein, M., Ferry, G. V., Chan, K. R., and Gary, B. L.: Particle size distributions in Arctic polar stratospheric clouds, growth and freezing of sulphuric acid droplets, and implications for cloud formation, J. Geophys. Res., 97, 8015-8034, doi:10.1029/91JD02740, 1992.

Fahey, D. W., Gao, R. S., Carslaw, K. S., Kettleborough, J., Popp, P. J., Northway, M. J., Holecek, J. C., Ciciora, S. C., McLaughlin, R. J., Thompson, T. L., Winkler, R. H., Baumgardner, D. G., Gandrud, B., Wennberg, P. O., Dhaniyala, S., McKinney, K., Peter, T., Salawitch, R. J., Bui, T. P., Elkins, J. W., Webster, C. R., Atlas, E. L., Jost, H., Wilson, J. C., Herman, R. L., Kleinböhl, A., and von König, M.: The Detection of Large $\mathrm{HNO}_{3}$-Containing Particles in the Winter Arctic Stratosphere, Science, 291, 10261031, doi:10.1126/science.1057265, 2001

Froidevaux, L., Jiang, Y. B., Lambert, A., Livesey, N. J., Read, W. G., Waters, J. W., Browell, E. V., Hair, J. W., Avery, M. A., McGee, T. J., Twigg, L. W., Sumnicht, G. K., Jucks, K. W., Margitan, J. J., Sen, B., Stachnik, R. A., Toon, G. C., Bernath, P. F., Boone, C. D., Walker, K. A., Filipiak, M. J., Harwood, R. S., Fuller, R. A., Manney, G. L., Schwartz, M. J., Daffer, W. H., Drouin, B. J., Cofield, R. E., Cuddy, D. T., Jarnot, R. F., Knosp, B. W., Perun, V. S., Snyder, W. V., Stek, P. C., Thurstans, R. P., and Wagner, P. A.: Validation of Aura Microwave Limb Sounder stratospheric ozone measurements, J. Geophys. Res., 113, D15S20, doi:10.1029/2007JD008771, 2008.

Grooß, J.-U.: Modelling of Stratospheric Chemistry based on HALOE/UARS Satellite Data, Ph.D. thesis, Universitat Mainz, 1996.

Grooß, J.-U., Brautzsch, K., Pommrich, R., Solomon, S., and Müller, R.: Stratospheric ozone chemistry in the Antarctic: what determines the lowest ozone values reached and their recovery?, Atmos. Chem. Phys., 11, 12217-12226, doi:10.5194/acp11-12217-2011, 2011.

Hanson, D. R. and Mauersberger K.: Laboratory studies of the nitric acid trihydrate: implications for the south polar stratosphere, Geophys. Res. Lett., 15, 855-858, doi:10.1029/GL015i008p00855, 1988.

Hanson, D. R. and Ravishankara, A. R.: Reaction of $\mathrm{ClONO}_{2}$ with $\mathrm{HCl}$ on NAT, NAD, and frozen sulfuric acid and hydrolysis of $\mathrm{N}_{2} \mathrm{O}_{5}$ and $\mathrm{ClONO}_{2}$ on frozen sulfuric acid, J. Geophys. Res., 96, 22931-22936, doi:10.1029/93JD01929, 1993. 
Hanson, D. R. and Ravishankara, A. R.: Reactive uptake of $\mathrm{ClONO}_{2}$ onto sulfuric acid due to reaction with $\mathrm{HCl}$ and $\mathrm{H}_{2} \mathrm{O}$, J. Phys. Chem., 98, 5728-5735, doi:10.1021/j100073a026, 1994.

Hanson, D. R., Ravishankara, A. R., and Solomon, S.: Heterogeneous reactions in sulfuric acid aerosols: A framework for model calculations, J. Geophys. Res., 99, 3615-3629, doi:10.1029/93JD02932, 1994.

Höpfner, M., Luo, B. P., Massoli, P., Cairo, F., Spang, R., Snels, M., Di Donfrancesco, G., Stiller, G., von Clarmann, T., Fischer, H., and Biermann, U.: Spectroscopic evidence for NAT, STS, and ice in MIPAS infrared limb emission measurements of polar stratospheric clouds, Atmos. Chem. Phys., 6, 1201-1219, doi:10.5194/acp-6-1201-2006, 2006.

IPCC (Intergovernmental Panel on Climate Change): Climate Change 2007: Synthesis Report, A Contribution of Working Groups I, II and III to the Fourth Assessment Report of the Intergovernmental Panel on Climate Change, edited by: Core Writing Team, Pachauri, R. K., and Reisinger, A., IPCC, Geneva, Switzerland, 2007.

Jöckel, P., Sander, R., Kerkweg, A., Tost, H., and Lelieveld, J.: Technical Note: The Modular Earth Submodel System (MESSy) - a new approach towards Earth System Modeling, Atmos. Chem. Phys., 5, 433-444, doi:10.5194/acp-5-433-2005, 2005.

Jöckel, P., Tost, H., Pozzer, A., Brühl, C., Buchholz, J., Ganzeveld, L., Hoor, P., Kerkweg, A., Lawrence, M.G., Sander, R., Steil, B., Stiller, G., Tanarhte, M., Taraborrelli, D., van Aardenne, J., and Lelieveld, J.: The atmospheric chemistry general circulation model ECHAM5/MESSy1: consistent simulation of ozone from the surface to the mesosphere, Atmos. Chem. Phys., 6, 50675104, doi:10.5194/acp-6-5067-2006, 2006.

Kerkweg, A., Sander, R., Tost, H., and Jöckel, P.: Technical note: Implementation of prescribed (OFFLEM), calculated (ONLEM), and pseudo-emissions (TNUDGE) of chemical species in theModular Earth Submodel System (MESSy), Atmos. Chem. Phys., 6, 3603-3609, doi:10.5194/acp-6-3603-2006, 2006.

Livesey, N. J., Read, W. G., Froidevaux, L., Lambert, A., Manney, G. L., Pumphrey, H. C., Santee, M. L., Schwartz, M. J., Wang, S., Cofeld, R. E., Cuddy, D. T., Fuller, R. A., Jarnot, R. F., Jiang, J. H., Knosp, B. W., Stek, P. C., Wagner, P. A., and Wu, D. L.: Earth Observing System (EOS) Aura Microwave Limb Sounder (MLS) Version 3.3 Level 2 data quality and description document, available at: http://mls.jpl.nasa.gov/data/datadocs.php (last access: 6 November 2014), 2011.

Kirner, O.: Prozessstudien der stratosphärischen Chemie und Dynamik mit Hilfe des Chemie-Klima-Modells ECHAM5/MESSy1, Ph.D. thesis, Universität Karsruhe, 2008.

Kirner, O., Ruhnke, R., Buchholz-Dietsch, J., Jöckel, P., Brühl, C., and Steil, B.: Simulation of polar stratospheric clouds in the chemistry-climate-model EMAC via the submodel PSC, Geosci. Model Dev., 4, 169-182, doi:10.5194/gmd-4-169-2011, 2011.

Landgraf, J. and Crutzen, P. J.: An efficient method for online calculations of photolysis and heating rates, J. Atmos. Sci., 55, 863-878, doi:10.1175/15200469(1998)055<0863:AEMFOC > 2.0.CO;2, 1998.

Lowe, D. and MacKenzie, A. R.: Polar stratospheric cloud microphysics and chemistry, J. Atmos. Sol.-Terr. Phy., 70, 13-40, doi:10.1016/j.jastp.2007.09.011, 2008.
Marti, J. and Mauersberger, K.: A survey and new measurements of ice vapor pressure at temperatures between 170 and $250 \mathrm{~K}$, Geophys. Res. Lett., 20, 363-366, doi:10.1029/93GL00105, 1993.

Meilinger, S. K.: Heterogeneous Chemistry in the Tropopause Region: Impact of Aircraft Emissions, Ph.D. thesis, Swiss Federal Institute of Technology (ETH), Zürich, 2000.

Müller, R., Peter, T., Crutzen, P. J., Oelhaf, H., Adrian, G. P., Von Clarmann, T., Wegner, A., Schmidt, U., and Lary, D.: Chlorine chemistry and the potential for ozone depletion in the arctic stratosphere in the winter of 1991/92, Geophys. Res. Lett., 21, 1427-1430, doi:10.1029/94GL00465, 1994.

Northway, M. J., Gao, R. S., Popp, P. J., Holecek, J. C., Fahey, D. W., Carslaw, K. S., Tolbert, M. A., Lait, L. R., Dhaniyala, S., Flagan, R. C., Wennberg, P. O., Mahoney, M. J., Herman, R. L., Toon, G. C., and Bui, T. P.: An analysis of large $\mathrm{HNO}_{3}$-containing particles sampled in the Arctic stratosphere during the winter of 1999/2000, J. Geophys. Res., 107, 8298, doi:10.1029/2001JD001079, 2002.

Peter, T. and Grooß, J.-U.: Polar Stratospheric Clouds and Sulfate Aerosol Particles: Microphysics, Denitrification and Heterogeneous Chemistry, in: Stratospheric Ozone Depletion and Climate Change, edited by: Müller, R., Roy. Soc. Chem., 108-144, doi:10.1039/9781849733182-00108, ISBN:978-1-84973-002-0, 2012.

Pitts, M. C., Poole, L. R., Dörnbrack, A., and Thomason, L. W.: The 2009-2010 Arctic polar stratospheric cloud season: a CALIPSO perspective, Atmos. Chem. Phys., 11, 2161-2177, doi:10.5194/acp-11-2161-2011, 2011.

Roeckner, E., Brokopf, R., Esch, M., Giorgetta, M., Hagemann, S., Koernblueh, L., Manzini, E., Schlese, U., and Schulzweida, U. Sensitivity of simulated climate to horizontal and vertical resolution in the ECHAM5 atmosphere model, J. Climate, 19, 37713791, doi:10.1175/JCLI3824.1, 2006.

Sander, R., Kerkweg, A., Jöckel, P., and Lelieveld, J.: Technical note: The new comprehensive atmospheric chemistry module MECCA, Atmos. Chem. Phys., 5, 445-450, doi:10.5194/acp-5445-2005, 2005.

Sander, S. P., Abbatt, J., Barker, J. R., Burkholder, J. B., Friedl, R. R., Golden, D. M., Huie, R. E., Kolb, C. E. Kurylo, M. J., Moortgat, G. K., Orkin, V. L. and Wine, P. H.: Chemical Kinetics and Photochemical Data for Use in Atmospheric Studies, Evaluation No. 17, JPL Publication 10-6, Jet Propulsion Laboratory, Pasadena, 2011.

Santee, M. L., MacKenzie, I. A., Manney, G. L., Chipperfield, M. P., Bernath, P. F., Walker, K. A., Boone, C. D., Froidevaux, L., Livesey, N. J., and Waters, J. W.: A study of stratospheric chlorine partitioning based on new satellite measurements and modeling, J. Geophys. Res., 113, D12307, doi:10.1029/2007JD009057, 2008.

Schlager, H. and Arnold, F.: Measurement of stratospheric gaseous nitric acid in the Winter arctic vortex using a novel rocket-borne mass spectrometer method, Geophys. Res. Lett., 17, 433-436, doi:10.1029/GL017i004p00433, 1990.

Shi, Q., Jayne, J. T., Kolb, C. E., Worsnop, D. R., and Davidovits, P.: Kinetic model for reaction of $\mathrm{ClONO}_{2}$ with $\mathrm{H}_{2} \mathrm{O}$ and $\mathrm{HCl}$ and $\mathrm{HOCl}$ with $\mathrm{HCl}$ in sulfuric acid solutions, J. Geophys. Res., 106, 24259-24274, doi:10.1029/2000JD000181, 2001. 
Solomon, S., Garcia, R. R., Rowland, F. S., and Wuebbles, D. J.: On the depletion of Antarctic ozone, Nature, 321, 755-758, doi:10.1038/321755a0, 1986.

Solomon, S., Daniel, J. S., Neely, R. R., Vernier, J. P., Dutton, E. G., and Thomason, L. W.: The Persistently Variable Background Stratospheric Aerosol Layer and Global Climate Change, Science, 333, 6044, 866-870, doi:10.1126/science.1206027, 2011.

Solomon, S., Haskins, J., Ivy, D. J., and Min, F.: Fundamental differences between Arctic and Antarctic ozone depletion, Proc. Natl. Acad. Sci., 111, 6220-6225, doi:10.1073/pnas.1319307111, 2014.

Tabazadeh, A., Toon, O. B., and Jensen, E. J.: Formation and implications of ice particle nucleation in the stratosphere, Geophys. Res. Lett., 24, 2007-2010, doi:10.1029/97GL01883, 1997.

Toon, O. B., Hamill, P., Turco, R. P., and Pinto, J.: Condensation of $\mathrm{HNO}_{3}$ and $\mathrm{HCl}$ in the winter polar stratospheres, Geophys. Res., Lett., 13, 1284-1287, doi:10.1029/GL013i012p01284, 1986.

Tost, H., Jöckel, P., and Lelieveld, J.: Influence of different convection parameterisations in a GCM, Atmos. Chem. Phys., 6, 54755493, doi:10.5194/acp-6-5475-2006, 2006.

Van Aalst, M. K.: Dynamics and Transport in the Stratosphere simulations with a general circluation model, Ph.D. thesis, Institute for Marine and Atmospheric Research Utrecht, Netherlands, 2005.

Van den Broek, M. M. P., Williams, J. E., and Bregman, A.: Implementing growth and sedimentation of NAT particles in a global Eulerian model, Atmos. Chem. Phys., 4, 1869-1883, doi:10.5194/acp-4-1869-2004, 2004.

Voigt, C., Schlager, H., Luo, B. P., Dörnbrack, A., Roiger, A., Stock, P., Curtius, J., Vössing, H., Borrmann, S., Davies, S., Konopka, P., Schiller, C., Shur, G., and Peter, T.: Nitric Acid Trihydrate (NAT) formation at low NAT supersaturation in Polar Stratospheric Clouds (PSCs), Atmos. Chem. Phys., 5, 13711380, doi:10.5194/acp-5-1371-2005, 2005.
Waters, J. W., Froidevaux, L., Harwood, R. S., Jarnot, R. F., Pickett, H. M., Read, W. G., Siegel, P. H., Cofield, R. E., Filipiak, M. J., Flower, D. A., Holden, J. R., Lau, G. K., Livesey, N. J., Manney, G. L., Pumphrey, H. C., Santee, M. L., Wu, D. L., Cuddy, D. T., Lay, R. R., Loo, M. S., Perun, V. S., Schwartz, M. J., Stek, P. C., Thurstans, R. P., Boyles, M. A., Chandra, K. M., Chavez, M. C., Chen, G. S., Chudasama, B. V., Dodge, R., Fuller, R. A., Girard, M. A., Jiang, J. H., Jiang, Y. B., Knosp, B. W., LaBelle, R. C., Lam, J. C., Lee, K. A., Miller, D., Oswald, J. E., Patel, N. C., Pukala, D. M., Quintero, O., Scaff, D. M., Van Snyder, W., Tope, M. C., Wagner, P. A., and Walch, M. J.: The Earth Observing System Microwave Limb Sounder (EOS MLS) on the Aura satellite, IEEE T. Geosci. Remote, 44, 1075-1092, doi:10.1109/TGRS.2006.873771, 2006.

Wegner, T., Grooß, J.-U., von Hobe, M., Stroh, F., SumińskaEbersoldt, O., Volk, C. M., Hösen, E., Mitev, V., Shur, G., and Müller, R.: Heterogeneous chlorine activation on stratospheric aerosols and clouds in the Arctic polar vortex, Atmos. Chem. Phys., 12, 11095-11106, doi:10.5194/acp-12-11095-2012, 2012.

Wohltmann, I., Wegner, T., Müller, R., Lehmann, R., Rex, M., Manney, G. L., Santee, M. L., Bernath, P., Sumińska-Ebersoldt, O., Stroh, F., von Hobe, M., Volk, C. M., Hösen, E., Ravegnani, F., Ulanovsky, A., and Yushkov, V.: Uncertainties in modelling heterogeneous chemistry and Arctic ozone depletion in the winter 2009/2010, Atmos. Chem. Phys., 13, 3909-3929, doi:10.5194/acp-13-3909-2013, 2013.

WMO (World Meteorological Organization), Scientific Assessment of Ozone Depletion: 2006, Global Ozone Research and Monitoring Project Report No. 50, Geneva, Switzerland, 2007. 